\title{
PENERAPAN MODEL PEMBELAJARAN KOOPERATIF TIPE JIGSAW SMP NEGERI 1 GIDO TAHUN PELAJARAN 2014/2015
}

\author{
Amin Otoni Harefa \\ FPMIPA, IKIP Gunungsitoli \\ e-mail: amin@ikipgunungsitoli.ac.id
}

\begin{abstract}
This reseach is aimed toDescribe quality of learning mathematics by using Cooperative Learning model, especially Jigsaw Type. Reseach method used is Claassroom Action Reseach, and problem that is found in this research are teaching learning process is sill used conventional method, students are passive in learning process, while the students' score averrage in the list of students' grade is 85 (A predicate).The findings of this reseach were: (1) The averrage of result of questionnaire of learning quality by using Cooperative Learning model, especially Jigsaw Type in the first cycle was 92,28\%, the second cycle was 88,25\%, and the third cycle was 90,21\%. So, the averrage was 90,25\% (Excellent Predicate), (2) The averrage of the students' learning outcomes by using Cooperative Learning model, especially Jigsaw Type in the first cycle was 30,23 (Poor), the second cycle was 43,28 (Poor), and the third cycle was 52,43 (Fair).
\end{abstract}

Keyword: Cooperative Learning Model by using Jigsaw Type

\begin{abstract}
Abstrak. Tujuan Penelitian: Mendeskripsikan kualitas pembelajaran dan hasil belajar matematika dengan menggunakan model pembelajaran kooperatif tipe Jigsau. Metode penelitian adalah merupakan penelitian tindakan kelas, dan masalah yang ditemukan adalah proses pembelajaran masih konvensional, siswa pasif dalam mengikuti proses pembelajaran, serta rata-rata hasil belajar siswa 85 kategori A-di DKN (dalam tanda kutip). Hasil Penelitian: 1. Rata-rata Hasil Angket Kualitas Pembelajaran dengan menerapkan Model Pembelajaran Kooperatif Tipe Jigsau pada Siklus I adalah 92,28\%, Siklus II adalah 88,25\%, dan pada Siklus III adalah 90,21\% sehingga rata-rata adalah 90,25\% (Amat Baik), 2. Rata-rata hasil belajar pada Siklus I adalah 30,23 (Sangat Kurang), pada Siklus II adalah 43,28 (Sangat Kurang), dan pada Siklus III adalah 52,43 (Cukup).
\end{abstract}

Kata Kunci: Model Pembelajaran Kooperatif Tipe Jigsaw 


\section{PENDAHULUAN}

Salah satu mata pelajaran yang mempunyai peranan dalam perkembangan IPTEK adalah mata pelajaran Matematika, tetapi masih banyak ditemukan kelemahan dan kekurangan baik dari pihak guru, siswa maupun perhatian pemerintah terhadap sekolah. Berdasarkan realita dilapangan keinginan belajar siswa pada mata pelajaran matematika masih kurang. Hal ini dibuktikan dengan hasil belajar siswa secara menyeluruh yang masih kurang jika dibandingkan dengan mata pelajaran yang lain. Salah satu faktor yang mempengaruhi hasil belajar siswa, yakni faktor intern dan faktor ekstern. Faktor intern terdiri dari keadaan fisikologis yaitu kondisi fisik, kondisi panca indera, dan keadaan psikologi sedangkan faktor ekstern terdiri faktor lingkungan yaitu lingkungan alam, lingkungan sosial, serta faktor instrumental yaitu kurikulum, guru, sarana, dan fasilitas administrasi.

\section{Hasil survei Tim di SMP Negeri 1}

Gido Kecamatan Gido Kabupaten Nias ternyata sebagian besar guru masih terikat dengan menggunakan pembelajaran konvesional, sehingga siswa cenderung pasif dalam mengikuti proses pembelajaran, karena sistem pembelajaran konvensional mengarah kepada metode ceramah dimana metode ceramah ini lebih banyak keaktifan guru dibandingkan peserta didik.

Begitu beragamnya permasalahan siswa dalam belajar diharapkan guru mampu memikirkan dan menentukan dengan tepat model pembalajaranapa yang digunakan sehingga permasalahan siswa dalam pembelajaran di kelas dapat teratasi.Adanya berbagai permasalahan belajar dan tersedia berbagai model pembelajaran berdasarkan KTSP maka guru diharapkan mampu untuk memadukan antara model pembelajaran yang digunakan dengan materi ajar, keterkaitan karakter siswa, serta sarana dan prasaranasa di sekolah.

Hasil studi pendahuluan pada tanggal 21 Februari 2015 oleh Tim peneliti di SMP Negeri 1 Gido Desa Hiliweto Kecamatan Gido Kabupaten Nias, kelas VIII-A ternyata ratarata hasil belajar siswa semester ganjil tahun pelajaran 2014/2015 adalah 85 dengan kategori A- berdasarkan sistem penilaian kurikulum tahun 2013. Akan tetapi waktu pelaksanaan PPLT di SMPN 1 Gido tersebut berdasarkan hasil pemantauan ketua tim peneliti selaku Dosen pembimbing PPLT/Penguji saat pelaksanaan ujian Praktek Pengalaman Lapangan Terpadu (PPLT) proses pembelajaran masih konvesional, berarti kurang sesuai tuntutan Kurikulum 2013 maupun KTSP, pertanyaan “ mengapa ratarata hasil belajar peserta didik khususnya di kelas VIII-A adalah 85 dengan kategori Adengan IP 3,66?"

Salah satu solusi untuk mengatasi hal di atas dengan menerapkan model pembelajaran kooperatif tipe Jigsaw.Menurut Daryanto dan Muljo Raharjo"Pembelajaran kooperatif merupakan model pembelajaran yang mengutamakan adanya kelompokkelompok" artinya dengan diterapkannya model pembelajaran ini maka adanya rasa 
kerjasama dan termotivasi siswa belajar sehingga diharapkanhasil belajar dapat lebih baik. Oleh tim peneliti melaksanakan penelitian secara ilmiah dengan judul "Penerapan Model Pembelajaran Kooperatif Tipe JigsawSMP Negeri 1 Gido Tahun Pelajaran 2014/2015".

\section{METODE}

Objek tindakan adalah penerapan model pembelajaran kooperatif tipe Jigsaw selama proses pembelajaran berlangsung baik pada siklus I dan siklus II.Lokasi penelitian di SMP Negeri 1 Gido, Jalan Pemuda No. 5 yang terletak di Desa Hiliweto Kecamatan Gido Kabupaten Nias.Subjek penelitian adalah siswa kelas VIII-A semester genap SMP Negeri 1 Gido tahun pelajaran 2014/2015, yang berjumlah 40 orang, 20 orang laki - laki dan 20 orang perempuan.

Pada penelitian ini sebanyak 3 (tiga) siklus. Siklus pertama terdiri dari 3 (tiga) kali pertemuan, dan satu kali akhir siklus, dan demikuian juga pada siklus II dan siklus III.

Untuk menganalisis data, maka tim peneliti melakukan langkah-langkah pengolahan sebagai berikut:

1. Pengolahan Hasil Observasi

$$
\text { Pengolahan hasil observasi }
$$
tentang siswa yang tidak aktif, siswa yang aktif dalam proses pembelajaran dan proses pembelajaran yang dilaksanakan oleh tim serta angket kualitas pembelajaran diolah secara statistik dan dinarasikan.

2. PengolahanTes Hasil Belajar
Pengolahan tes hasil belajar diolah berdasarkan KTSP dengan langkahlangkah teknik evaluasi, dengan kriteria, sebagai berikut :

$$
\begin{aligned}
& 86-100=\text { baik sekali } \\
& 71-85=\text { baik } \\
& 56-70=\text { cukup } \\
& 41-55=\text { kurang } \\
& 0-40=\text { sangat kurang }
\end{aligned}
$$

3. Pengolahan Hasil Wawancara

Data hasil wawancara kepada siswa tentang kegiatan guru (peneliti) dalam proses pembelajaran akan dinarasikan serta merupakan bahan bandingan terhadap instrumen lainnya.

\section{HASIL DAN PEMBAHASAN}

Hasil pembahasan temuan penelitian, peneliti menyimpulkan:

1. Pelaksanaan proses pembelajaran dengan menggunakan model pembelajaran Jigsau sangat baik jika diterapkan sesuai dengan kajian teori dalam proses pembelajaran.

2. Hasil belajar tidak tercapai sebagaimana yang diharapkan, disebabkan karena ratarata nilai siswa yang tercantum dalam daftar kumpulan nilai (DKN) disaat observasi tidak sesuai dengan prestasi siswa dalam arti nilai mereka adalah hasil yang ditambah oleh guru bidang studi, ratarata hasil belajar adalah 85 , sehingga peneliti merencanakan target nilai rata-rata adalah 90, dan hal ini ternyata disaat peneliti mewawancarai guru bidang studi 
ternyata benar bahwa nilai peserta didik setiap pelaksanaan ujian semester selalu ada penambahan nilai dari guru mata pelajaran secara merata dengan tujuan agar pada penentuan kelulusan pada Kelas IX pada akhir tahun pelajaran dapat lulus.

3. Hasil analisis simpangan baku: pada akhir Siklus I adalah 6,23; pada akhir Siklus II adalah 9,17, dan pada akhir Siklus III adalah 13,21 artinya kemampuan peserta didik kelas VIII A pada pelaksanaan ujian ulangan pada siklus I dan, siklus II tidak jauh perbedaan antara yang mampu menjawab dengan yang tidak mampu menjawab, sedangkan pada Siklus III perbedaan antara yang mampu dengan yang tidak mampu sangat jauh, dan terbukti juga bahwa hasil ujian ulangan nilai siswa yang tertinggi adalah 76 (dua orang di atas standar KKM MP dan tuntas hanya 5\%),serta nilai terendah adalah 16 (48 orang dibawah standar KKM MP, dan tidak tuntas $95 \%$ ).

4. Rata-rata hasil angket kualitas proses pembelajaran berdasarkan dimensi adalah 90,25\% (amat baik), karena selama proses pembelajaran selalu menggunakan power point sehingga peserta didik sangat antusias belajar/mengikuti proses pembelajaran.

5. Berdasarkan analisis hasil belajar setiap akhir siklus, hendaknya nilai Kriteria Ketuntasan Minimal mata pelajaran (KKM MP) matematika ditinjau ulang, karena tidak sesuai dengan kemampuan bidang kognitif peserta didik.

\section{SIMPULAN (PENUTUP)}

Berdasarkan hasil analisis dan pengolahan data serta untuk menjawab tujuan penelitian, maka dapat disimpulkan sebagai berikut:

1. Deskripsi hasil Angket Kualitas Proses

Pembelajaran, sebagaimana tabel berikut:

Tabel 1 Hasil Angket Kualitas Proses

Pembelajaran

\begin{tabular}{lccc}
\hline \multirow{2}{*}{ Dimensi } & \multicolumn{3}{c}{ Akhir Siklus (\%) } \\
\cline { 2 - 4 } & I & II & III \\
\hline $\begin{array}{l}\text { Strategi } \\
\text { Pengorganisasian } \\
\text { Pembelajaran }\end{array}$ & $92,56 \%$ & 87,01 & 89,24 \\
\hline $\begin{array}{l}\text { Strategi } \\
\text { Penyampaian } \\
\text { Pembelajaran }\end{array}$ & $91,70 \%$ & 90.54 & 91,56 \\
\hline $\begin{array}{l}\text { Strategi } \\
\text { Pengelolaan } \\
\text { Pembelajaran }\end{array}$ & $92,58 \%$ & 87,20 & 89,83 \\
\hline \multicolumn{1}{c}{ Rata-rata } & $92,28 \%$ & $88,25 \%$ & $90,21 \%$ \\
\hline Rata-rata Akhir & \multicolumn{3}{c}{90,25} \\
\hline \multicolumn{4}{c}{ Kategori }
\end{tabular}

2. Deskripsi hasil belajar sebagaimana tebel berikut:

\section{Tabel 2 Hasil Belajar}

\begin{tabular}{|c|c|c|c|c|c|c|}
\hline \multirow{2}{*}{$\begin{array}{c}\text { Hasil } \\
\text { Penghitun } \\
\text { gan }\end{array}$} & \multicolumn{6}{|c|}{ Akhir Siklus } \\
\hline & I & Kategori & II & $\begin{array}{c}\text { Kateg } \\
\text { ori }\end{array}$ & III & $\begin{array}{c}\text { Kateg } \\
\text { ori }\end{array}$ \\
\hline $\begin{array}{c}\text { Rata- } \\
\text { rata } \\
\text { hasil } \\
\text { belajar }\end{array}$ & 30,23 & $\begin{array}{l}\text { Sangat } \\
\text { Kurang }\end{array}$ & 43,28 & $\begin{array}{l}\text { Sangat } \\
\text { Kurang }\end{array}$ & 52,43 & $\begin{array}{c}\text { Cuku } \\
\mathrm{p}\end{array}$ \\
\hline $\begin{array}{c}\text { Simpan } \\
\text { gan } \\
\text { Baku }\end{array}$ & 6,23 & - & 9,17 & - & 13,21 & - \\
\hline $\begin{array}{l}\text { Tidak } \\
\text { Tuntas }\end{array}$ & $100 \%$ & - & $100 \%$ & - & $95 \%$ & - \\
\hline Tuntas & $0,0 \%$ & - & $0,0 \%$ & - & $5 \%$ & - \\
\hline
\end{tabular}

\section{UCAPAN TERIMAKASIH}

Pada penelitian ini, banyak kontribusi dari berbagai pihak sehingga penelitian ini bisa 
selesai. Peneliti mengucapkan terimakasih kepada Pimpinan dan seluruh pihak Sekolah di SMP Negeri 1 Gido yang telah mendukung dan memberikan kesempatan, waktu dan tempat dalam melakukan penelitian ini.

\section{DAFTAR PUSTAKA}

Arikunto Suharsimi, 2012. Dasar-dasar Evaluasi Pendidikan. PT Bumi Aksara, Jakarta

Anas Sudijono, 2012. Pengantar Evaluasi Pendidikan. PT RajaGrafindoPersada. Jakarta

Darianto dan Rahardjo, Muljo, 2012. Model Pembelajaran Inovatif. Gava Media, Yokyakarta

Djamarah, Syaiful Bahri dan Zain, Aswan. 2010. Strategi Belajar Mengajar. PT Rineka cipta, Jakarta

Istarani, 2011. Model Pembelajaran Inovatif. Media Persada, Medan.

Mulyasa, E, 2006. Kurikulum Yang Sempurna. PT Remaja Rosdakarya, Bandung.

Sanjaya, Wina H, 2010. Strategi Pembelajaran Berorientasi Standar Proses Pendidikan. Kencana Prenada Media Group, jakarta.

Sanjaya, Wina H, 2011. Pembelajaran Dalam Implementasi Kurikulum Berbasis Kompetensi. Kencana Prenada Media Group, jakarta.

Sudjana, H.D, 2010. Strategi Pembelajaran. Falah, Bandung.

Tim Pustaka Yustisia, 2008. Panduan Lengkap KTSP. Pustaka Yustisia, Yogyakarta. 